\title{
META-SOBŌR *
}

\section{WPROWADZENIE}

Rok temu miałem sposobność wzięcia udziału w kolokwium poświęconym obiektywności moralnej w Uniwersytecie w Navarre ${ }^{1}$. Niewielka książeczka pozwoliła mi na rozwinięcie tematu mojego odczytu: „Odróżniać dobro od zła" 2 .

$\mathrm{Na}$ kolokwium, tak jak i w książce mówiłem o meta-soborze, o dewiacjach, które niekiedy narzucano prawdziwej nauce soborowej. Tam właśnie padały przyjacielskie pytania: co ksiądz rozumie przęz meta-sobór?, jakie doktrynalne stanowiska duszpasterskie rodzą się z tego meta-soboru?

$\mathrm{Na}$ te właśnie pytania chciałem już wcześniej odpowiedzieć i będę się starał odpowiedzieć tutaj. Jest jednak rzeczą konieczną, bym na wstępie określił moje intencje.

Mówić o meta-soborze, to znaczy oczywiście krytykować fałszywą interpretację Vaticanum II. Ale na skutek swego rodzaju nieuniknionego uproszczenia psychologicznego ryzykuję posądzenie o krytykowanie samego Soboru. A przecież nie to jest moją intencją. Przeciwnie, jeśli ujawniam deformacje Soboru, to jedynie po to by uwypuklić wartości samego Soboru. Jestem przekonany, że te wielkie posiedzenia Magisterium i jego Hierarchii były łaską od Boga, a naszym obowiązkiem jest wydobyć z niej jak najwięcej.

Mój punkt widzenia leży więc na antypodach wszystkich możliwych paseizmów: integryzmu bpa Marcela Lefebvre, paseizmu tych, którzy uważają, że najlepiej byłoby „naprawić to co zniszczył Sobór”. Jan Paweł II ustalił nam program: cały Sobór, nic tylko Sobór ${ }^{3}$.

* Tekst oryginalny w Esprit et Vie, $\mathrm{nr} 39-25$, wrzesień 1980, s. 513-526.

1 I Simposio internacional de teologia, Etica y Teologia ante la crisis contemporanea, edicion preparada por la Comision Cienitifica del Simposio, J. L. Illanes (director), P. Gr. Alves de Sousa, T. Lopez, A. Sarmiento, Ediciones Universidad de Navarra, Pampelona, 1980, s. 661.

$2 \mathrm{Ph}$. Delhaye, Discerner le bien du mal, Cahiers du livre, Chambray-les-Tours, 1980 , s. 171.

3 Jan Paweł II, Lettre à l'Episcopat allemand au sujet de l'affaire Küng (15.5.80) w l'Osservatore Romano français z 17 lutego 1980 , s. 2. 
Nie znaczy to, że niedawny Sobór położył kres ewolucji myśli i życia Kościoła. Musi istnieć post-sobór, jak to zaraz wyjaśnimy. Jednakże problemem tego artykułu jest coś zupełnie innego: a mianowicie taka interpretacja Vaticanum II, która stara się obarczyć go odpowiedzialnością za doktryny i stanowiska, których nigdy na siebie nie brał.

Deformacje Soboru mogą leżeć na wielu płaszczyznach i w licznych perspektywach. Dlatego właśnie, uściśliwszy sens użytego terminu, przyjrzyjmy się paru typom deformacji: źle interpretowane milczenia, transformacje nauczania soborowego, zakłócenia równowagi w dziedzinie doktryny i duszpasterstwa, fałszywe slogany. Będziemy zmuszeni poprzestać na przedstawieniu po jednym charakterystycznym dla każdej kategorii przypadku. Chcąc przedstawić pełny obraz należałoby napisać summę. Skończymy omawianie tematu sugerując parę środków zaradczych.

I. SOBOR, POST-SOBOR, PARA-SOBOR, META-SOBOR

\section{Sobór i post-Sobór}

Zapomnieliśmy być może o tym, ale zawsze trzeba było wiele czasu by wielkie Sobory mogły zdobyć akceptację i pełne wprowadzenie w praktykę. Nie cofajmy się aż do potopu i pomyślmy choćby o Soborze Trydenckim. Potrzeba będzie aż trzech generacji, by ponownie całkowicie wprowadzić spowiedź uszną, zakładać seminaria, zreformować proboszczów, zakonników, kanoników i uzyskać obowiązek rezydowania biskupa $\mathrm{w}$ swojej diecezji.

Należy więc pogodzić się z tym, że konieczny jest „,czas utajony”, czas akceptacji psychologicznej i podjęcia decyzji. Chciałbym tu dodać, że mówiąc to nie przypisuję sobie autorstwa tezy kilku teologów z XVII i XVIII wieku o akceptacji doktrynalnej, takiej jaką niedawno podjęło parę osób. Dla tych profesorów, Sobór-nie miałby, zwłaszcza z punktu widzenia doktryny, wartości definitywnej, jeżeli nie zostałby przyjęty przez Sobór następny lub przez opinię publiczną w Kościele.

Perspektywy te wydają mi się fałszywe z wielu punktów widzenia. $\mathrm{Na}$ planie ściśle doktrynalnym, autorytet Magisterium i Hierarchii nie jest uzależniany od akceptacji przez wiernych obecnych lub przyszłych. Chrystus daje exousia Apostołom, a oni sprawują ją bezwarunkowo. Lumen Gentium, w 25 potwierdza to raz jeszcze po Vaticanum I. Nie będzie bezużytecznym ponowne odczytan tego tekstu, ponieważ, powtarzam, po roku 1965, pewna liczba profesorów twierdziła, że nauczanie Kościoła było ważne tylko o tyle, o ile zostało „zaakceptowane”. Po omówieniu 
nieomylności Magisterium w jej rozlicznych formach (papież, sobór ekumeniczny, jednomyślność episkopatu) Lumen Gentium dodaje:

„Ta nieomylność, w którą Boski Odkupiciel żechciał wyposażyć Kościół swój w określaniu nauki wiary lub obyczajów, ma taki zakres, jak i depozyt boskiego Objawienia, który ma być ze czcią przechowywany i wiernie wykładany. Nieomylnością tą z tytułu swego urzędu cieszy się Biskup Rzymski, Głowa Kolegium Biskupiego, gdy jako najwyższy pasterz i nauczyciel wszystkich wiernych Chrystusowych, który braci swych umacnia w wierze (por. Ek 22, 32), ogłasza definitywnym aktem naukę dotyczącą wiary i obyczajów. Toteż orzeczenia jego słusznie zwane są nienaruszalnymi same $z$ siebie, a nie na mocy zgody Kościoła, jako że ogłoszone zostały z pomocą Ducha Świętego przyrzeczoną mu w osobie św. Piotra i dlatego nie potrzebuja niczyjej aprobaty ani nie dopuszczaja odwoływania się do niczyjego sądu. Wówczas bowiem Biskup Rzymski nie wyraża sądu jako osoba prywatna, lecz jako najwyższy nauczyciel Kościoła powszechnego, któremu przysługuje w szczególniejszy sposób charyzmat nieomylności samego Kościoła, wykłada naukę wiary katolickiej lub bierze ją w obronę. Nieomylność obiecana Kościołowi przysługuje także Kolegium Biskupiemu, gdy wraz z następcą Piotra sprawuje ono najwyższy urząd nauczycielski. Orzeczeniom tym nie może nigdy zabraknąć zgody Kościoła, a to z powodu działania jednego i tego samego Ducha Swiętego, dzięki któremu to działaniu cała trzoda Chrystusowa utrzymuje się w jedności wiary i czyni w niej postępy".

Niewątpliwie ten tekst soborowy mówi głównie o nieomylnej nauce Kościoła, na którą Jan Paweł II znów zwrócił uwagę odpowiadając na błędy Hansa Künga ${ }^{4}$. Niewątpliwie również należałoby wyraźniej niż to się czyni od stu lat, odróżnić nauczanie nadzwyczajne i nauczanie zwyczajne Magisterium ${ }^{5}$. To wszystko jednak nie znaczy, że nauki nie obdarzone charyzmatem nieomylności pozbawione są wszelkiego autorytetu. Lumen Gentium, (rozdz. 25) przypomina doktrynę Kościoła na ten temat:

„Biskupom nauczającym w łączności z papieżem należy się od wszystkich cześć jako świadkom boskiej i katolickiej prawdy; wierni zaś winni zgadzać się ze zdaniem swego biskupa w sprawach wiary i obyczajów, wyrażonym w imieniu Chrystusa, i trwać przy nim w religijnej uległości. Tę zaś zbożną uległość woli i rozumu w sposób szczególny okazywać na-

${ }^{4}$ Por. Ph. Delhaye, „L'affaire Hans Kün”” w'Esprit et Vie, 1980, s. 218-221, $241-248,257-269,273-283$.

5 Pamiettam jeszcze to, co mówiono i pisano na ten temat prized wojną. W ,La Libre Belgique” w 1935 r. Ageorge pisał w swoim „Billet de Paris”: „Nie chcę znać granic nieomylności papieskiej. Jeżeli papież jest nieomylny, jest nim zawsze". Jakie to dziwne i smutne, kiedy zauważy się, że ,z drugiej strony” tej opinii, Hans Küng rozumuje^nieinaczej. Jego argumentacja przeciw nieomylności bierze swój początek w rodzaju literackim encyklik. One przecież nie są nieomylne same przez się, nawet jeżeli, jak sądzą niektórzy, powtórzenie istotnych danych jakiego dokonują stanowi naukę zwyczajną nieomylną. 
leży autentycznemu urzędowi nauczycielskiemu Biskupa Rzymskiego nawet wtedy, gdy nie przemawia on ex cathedra; trzeba mianowicie ze czcią uznawać jego najwyższy urząd nauczycielski i do orzeczeń przez niego wypowiedzianych stosować się szczerze, zgodnie z jego myślą i wolą, która ujawnia się szczególnie przez charakter dokumentów, bądź przez częste podawanie tej samej nauki, bądź przez sposób jej wyrażania."

Możemy do samego Soboru zastosować tę hermeneutykę i widzieć w niej prawdziwą deklarację intencji. Choć Vaticanum II nie uznało za konieczne uciekanie się do form nauczania nadzwyczajnego celem dokonania nowych stwierdzeń dogmatycznych, to niemniej powtarza sporą liczbę dogmatów. W dziedzinie ,wiary do wierzenia i do życia nią", tak jak i w dziedzinie duszpasterskiej, XXI Sobór Ekumeniczny używa dróg zwykłego Magisterium, nie rozproszonego, jak to często bywało w przeszłości, ale zjednoczonego w czasie nasilonej kolegialności. I tak właśnie, zamierza nauczać, z racji swojego charyzmatu, a nie z racji uznania przez Kościół. Przeciwnie, wszyscy wierni winni być posłuszni Duchowi, słuchając swych pasterzy ${ }^{6}$.

$\mathrm{Z}$ drugiej strony, na planie egzystencjalnym, nie umiem sobie wyobrazić w jaki sposób problem prawdy mógłby być rozwiązany przez opinię publiczną. Niektórzy filozofowie, jak np. Reid w XIX wieku, uważali ją za najwyższe kryterium. Psychologowie jednak wykazali później niższy charakter poziomu refleksji, z którego ta opinia bierze początek ${ }^{7}$. Widzę, że Duch Swwięty może posłużyć się tym wspólnym fundamentem jako świadectwem sensus fidelium. Ale czego doty,czy ta zgoda? Kiedy Vaticanum II mówi o „sensus fidelium”, umieszcza go "w kontekście $\mathrm{Pa}$ sterzy i Magisterium. Przeczytajmy ponownie co na ten temat mówi paragraf 12 Lumen Gentium:

„Swięty Lud Boży ma udział w proroczej funkcji Chrystusa, szerząc żywe w Nim świadectwo przede wszystkim przez życie wiary i miłości i składając Bogu ofiarę chwały, owoc warg wyznających imię Jego (por. Hbr 13, 15). Ogół wiernych, mających namaszczenie od Swiętego (por. 1 J 2, 20 i 27), nie może zbłądzić w wierze i tę szczególną swoją właściwość ujawnia poprzez nadprzyrodzony zmysł wiary całego ludu, gdy "poczynając od biskupów aż po ostatniego z wiernych świeckich" ujawnia on swą powszechną zgodność w sprawach wiary i moralności. Albo-

${ }^{6}$ Próbowałem sprecyzować autorytet nauki Soboru w artykule Vatican II w Tables Dictionnaire de Théologie catholique col. 4286-354.

7 Już G. Lebon pokazał dwuznaczności i luki opinii kolektywnej w Psychologie des foules. Niedawno, te przestrogi zostały ponownie zebrane przez J. Stoetzela, La psychologie sociale, Paris 1963 (szczególnie rozdz. XIII, s. 256 i nn.: l'Opinion publique et l'information collective) i przez F. Balle, Institutions et publics des moyens d'information, presse, radiodiffusion, télévision, Paris, Ed. Montchrestien, 1973. Zauważmy również ostrzeżenie Kardynała Gouyon, Foi, morale, sondage w L'Osservatore Romano français, z 24 czerwca 1980 s. 8. 
wiem dzięki owemu zmysłowi wiary, wzbudzanemu i podtrzymywanemu przez Ducha prawdy, Lud Boży pod przewodem świętego urzędu nauczycielskiego - za którym wiernie idąc, już nie ludzkie, lecz prawdziwie Boże przyjmuje słowo (por. 1 Tes 2, 13) - niezachwianie trwa "przy wierze raz podanej świętym « (Jud 3), wnika w nią głębiej z pomocą słusznego osądu i w sposób pełniejszy stosuje ją w życiu".

Ale, powtórzmy to jeszcze raz, czym innym jest akceptacja doktrynalna a czym innym akceptacja psychologiczna. Kiedy kończy się jakiś Sobór, należy jeszcze przekazać jego naukę, jego zalecenia, całemu ciału eklezjalnemu. Można powieđzieć, że w przypadku Vaticanum II wysiłki te trwały aż do 1968 r., pomimo pewnych akcji hamujących, przychodzących nieraz z góry, akcji, których potem żałowano.

Do tej integracji dodałbym ruch post-soborowy. Seria tekstów, wedle klasycznej formuły, tak jak człowiek nie jest kamieniem milowym, ale latarnią. Zasady Konstytucji Liturgicznej normalnie winny były znaleźć kontynuację w reformie ksiąg liturgicznych. Nowy mszał ukazał się w 1969 roku, a nowy brewiarz w $1971 \mathrm{r}$. (chociaż trzeba było prawie 10 lat, by adaptacja francuska dotarła do publiczności) ${ }^{8}$. Innym przykładem byłyby Synody biskupów, które zbierają się co 3 lub 4 lata, i które ciągle szukają własnej drogi, chociaż przyniosły już znakomitą współpracę Kurii z diecezjami.

\section{Meta-Sobór, para-Sobór}

Obok tych przedłużeń w czasie, które są znakami życia, istnieją inne aspekty czasu posoborowego, zasługujące na odmienny osąd. Chcę mówić o przekroczeniach, przeinaczeniach, które nie przestają się mnożyć.

Wszystko odbywa się tak, jak gdyby niektórzy periti, niezadowoleni, że nie zdołali przeprowadzić akceptacji swoich idei przez Sobór, w parę lat później sami przypisali je Soborowi. Tak właśnie O. H. de Lubac widzi sprawę O. E. Schillebeeckxa, a zwłaszcza eseju, w którym ten ostatni usiłuje zlikwidować różnicę między ,ubóstwieniem człowieka” przez Chrystusa i „uczłowieczeniem" 9. Na płaszczyźnie liturgicznej sprawy te są łatwiejsze do sprawdzenia, gdyż mszał Pawła VI był sam’ w sobie bar-

8 Jeśli nawet księgi liturgiczne wydane przez Kongregację Kultu Bożego stanowią część post-Soboru, nie znaczy to, że pewne adaptacje czy tłumaczenia nie należą do meta-Soboru. Ta trafna uwaga została sformułowana-przez słuchaczy pewnego odczytu, który posłużył jako kanwa tego artykułu. Konkretne przykłady znajdziemy w J. Renié, Missale Romanum et Missel Romain, Paris Le Cèdre, 1975.

${ }_{9}$ Henri de Lubac, Petite catéchèse sur nature et grâce, Coll. Communio, Paris, Fayard, 1980, s. 222. - O wiele lepiej ode mnie O. de Lubac wskazuje na fałszywe interpretacje Soboru. Z całą słusznością skupia je na największej z nich: próbie zniesienia rozróżnienia między udoskonaleniem człowieka i zbawieniem w Chrystusie. 
dzo rzadko używany. Natychmiast stał się kanwą, wokół której snuto tysiące wariacji.

W wypadkach tych nie ma jednorodnego rozwoju, ale różnorodny: zerwania, przekroczenia, a nawet negacje. W 1972 r. O. Yves Congar mówił mi: „To bardzo smutne, ale opinia publiczna szalenie uprościła sprawy. Dla opinii, wszystko co poprzedza Vaticanum II, jest przestarzałe. Dla niej też po Soborze wszystko musi być nawe".

$\mathrm{Z}$ tego powodu, coraz więcej autorów - a zwłaszcza ci, którzy przeżyli Sobór - z wielką starannością rozróżniają post-Sobór od para-Soboru i meta-Soboru. Jak już mówiliśmy, O. de Lubac chętnie używa terminu para-Sobór. I ja tak czynię. W ten sposób można pokazać, że wiele spraw przypisywanych Soborowi nie należy do niego, jest marginalnych, obcych.

Ale czy to wystarczy? Nie zawsze łatwo wyznaczać linię demarkacyjną między post-Soborem i para-Soborem. Liczne aktualne i chwalebne inicjatywy czy idee, są zarazem post-soborowe i para-soborowe. Dlatego właśnie ktoś pomyślał o określeniu „meta-soborowy”. Określenie to nie cznacza tylko tego, co jest obce Soborowi, ale również to, co jest jego zdradą, co go fałszuje, wprowadza zerwanie lub negację.

Być może zastosowanie tego meta-, tłumaczy się wielką liczbą słów używanych do określenia, zwłaszcza $\mathrm{w}$ naukach humanistycznych i doświadczalnych, przekroczenia, które jest zamiarem umniejsżenia lub zaprzeczenia temu, czego wcześniej dokonano. Meta-muzyka pragnie odsunąc muzykę zbyt namiętną i sentymentalną. Meta-moralność stara się zastąpić moralności wynikające $\mathrm{z}$ obowiązku, poprzez zwykły opis socjologiczny faktów, meta-geometria wykracza poza system euklidesowy ${ }^{10}$.

W przemówieniu, które Jan Paweł II wygłosił do Konferencji Episkopatu francuskiego, w Issy-les-Moulineaux, 1 czerwca $1980^{11}$, pojawia się wyrażenie „meta-pokusy”: „Kuszenie współczesne idzie jednakże dalej (jakby "meta-pokusa«) zmierza „poza" wszystko, co w ciągu dziejów stanowiło temat kuszenia człowieka, a zarazem objawia jakby »dno" wszelkiego kuszenia. Człowiek współczesny jest poddany pokusie odrzucenia Boga w imię własnego człowieczeństwa" ${ }^{12}$.

10 P. Foulquie, Dictionnaire de la langue philosophique, P.U.F., Paris, 1962, s. $436-437$.

11 Jan Pawel II, Discours aux Evêques français, w l'Osservatore Romano français, 3 czerwca 1980 , s. 16 - Zauważmy także to zalecenie papieża, na które staramy się tutaj odpowiedzieć: „Naszym wspólnym zadaniem pozostaje przyjęcie i realizacja Vaticanum II wedle jego autentycznej zawartości. Kierujemy się przy tym motywem wiary jako motywem zasadniczym i podstawowym".

12 Tutaj znowu wyraża się to, co jest meta-Soborem: egzaltacja człowieka ,samego" pomijając dzieło stworzenia i odkupienia Boga. Negacja nie jest wymierzona jedynie przeciw Bogu i historii zbawienia, ale także na człowieka-obraz Boga, $\mathrm{w}$ odniesieniu do Boga. Dochodzimy tu w pewien sposób do przeciwieństwa, jakie wyraźnie zaznaczał św. Paweł między człowiekiem usprawiedliwionym przez łaskę 
Jeśli zastosujemy te cechy charakterystyczne do określenia „,meta-sobór", możemy również dorzucić następne elementy. Meta-sobór idzie o wiele dalej niż Sobór. Sięga do głębi (dna) różnic, próbuje zaprzeczyć Soborowi, jednocześnie biorąc go za punkt odniesienia.

Byłoby rzeczą bezużyteczną próbować narzucić tu słownictwo mające wejść do powszechnego użytku, potoczne. Nie można jednak odebrać badaczom prawa do tworzenia neologizmów, pod warunkiem że wytłumaczą ich sens. Niezależnie od tego czy przyjmiemy, czy też odrzucimy określenie „meta-sobór”, które coraz bardziej się rozpowszechnia, nie można zaprzeczyć istnienia radykalnych transformacji, jakie różne kierunki myślenia podsuwają II Soborowi Watykańskiemu.

\section{II. ŹLE INTERPRETOWANE MILCZENIA}

Jedną z niespodzianek wydania "Concordance de Vatican II" ${ }^{13}$ było stwierdzenie całkowitego lub prawie całkowitego milczenia Soboru w sprawie ważnych tematów czy terminów. Zacytuję trzy z nich: pluralizm, kolegialność, grzech pierworodny. Śpieszę zresztą dodać, że przemilczenia te były różnorodnie interpretowane, ponieważ wedle słynnego rozróżnienia de Gaulle’a była tam i „nicość” i „nadmiar”. Czegóż nie napisano o pluralizmie! ${ }^{14}$ Gdzie nie stosowano kolegialności! ${ }^{15}$ Nie twierdzę, że zawsze niesłusznie, stwierdzam wszakże pewną różnicę, gdyż trzykrot-

i człowiekiem, który twierdzi, że zbawi się sam, własnymi siłami. - W dziedzinie poznania znajdujemy te same tendencje. Rzuca się wyzwanie Słowu Boga, które ludzie otrzymują od Kościoła w wierze (do wierzenia i do przeżycia) i które starają się zrozumieć i przedłużyć umysłem. Na jego miejsce daje się nowe nauki humanistyczne: freudyzm, marksizm itd. i w najlepszym wypadku stara się dostosować do ich sensu, Słowo Boga. Co w wypadku Soboru oznacza, nie to co Sobór powiedział, tylko to, co chciałoby się, żeby porwiedział (co się mu przypisuje).

${ }_{13} \mathrm{Ph}$. Delhaye, M. Gueret, P. Tombeur, Concilium Vaticanum II, Concordance, index, listes de fréquence, tables comparatives, Louvain-la-Neuve, Cetedoc-Tedm, 1974, s. 978 (por. Esprit et Vie, 1975, s. 32).

${ }_{14}$ Konieczne były uściślenia. Można zobaczyć jako przykład: Kard. J. Ratzinger, Quinze thèses sur l'unité de la foi et le pluralisme théologique. Cahiers du Livre, Chambray-les-Tours, 1978 s. 147. W niektórych śnodowiskach całkiem odmiennych od tych, które mówiły o pluralizmie w Kościele, akreślenie pluralizm kieruje się w stronę waloryzacji tego co kiedyś nazywano „wolną myślą” lub „myślą laicką".

15 Jeśli nawet Vaticanum II nie mówi o collegialitas, to niejednokrotnie używa określenia collegium episcoporum lub corpus episcoporum. Niektórzy członkowie Soboru nie używali określenia ,collegium”, ponieważ w prawie rzymskim, prezydent kolegium jest primus inter pares, a nie jest nim Papież w stosunku do biskupów. Należy się jednak zastanowić, czy kiedy biskupi Starożytnego Kościoła mówili o collegium, nie używali analogii $\dot{i} \mathrm{w}$ żadnym wypadku nie starali się zastosować terminu prawniczego w pełnym jego znaczeniu. - W każdym razie, po Soborze (post, para, meta- nie wiem już jak) kolegialność stała się terminem oznaczającym każdą współ-odpowiedzialność i każdy podział władzy, w dowolnym środowisku. - Zauważmy à propos odważne na ten temat uściślenia Ojca Swiętego w jego przemówieniu z 28 czerwca 1980 r.: „Biskupia kolegialność i misja prymatu Piotra". L'Osservatore Romano français z 8.7.1980. nr 28, s. 4.

24 - Analecta Cracoviensia 
nie wspomniane originalis labes, nie zostały rozwinięte ani wytłumaczone ${ }^{16}$. Milczenie to ociera się o negację, a w każdym razie inspiruje stanowiska i słowa, które do negacji dążą.

\section{Grzech pierworodny}

Niektórzy to przewidzieli. Przypominam sobie, że kardynał Micara, obłożnie chory, kazał przeczytać in aula surowy list na temat Lumen Gentium. Oznajmiał w nim, że nie może głosować na tekst nie wysuwający na pierwszy plan zasadniczych dogmatów, takich jak grzech pierworodny. Ogólna opinia nie poszła za jego zdaniem i uznała, że niebezpieczeństwo jest przesadzone.

Przy tej okazji przypomniano, że papież Jan XXIII powiedział w inauguracyjnym przemówieniu: „Vaticanum II zapisuje się w całym szeregu Soborów, jak na przykład Trydencki i Vaticanum I. Zbytecznym jest ich powtarzanie, trzeba je przetłumaczyć". - Afirmacja grzechu pierworodnego była oczywiście zawarta w sposób najbardziej wymowny w aktach Soboru Trydenckiego, które zebrały wszystko co na ten temat mówi Tradycja i Pismo, a zwłaszcza List do Rzymian $5^{17}$.

Można się jednak zastanawiać czy meta-Sobór nie spowodował tego rozdarcia między Vaticanum II i poprzednimi soborami. Czyż nie przedstawiał niejednokrotnie Soboru z lat 1962 - 65 jako anty-Trydent, anty-Vaticanum ${ }^{18}$ ? Jest się skłonnym sądzić, że taka właśnie jest pozycja meta-Soboru, kiedy pomyśli się o pewnych słowach czy stanowiskach dotyczących grzechu pierworodnego.

A propos grzechu pierworodnego, chciałbym przypomnieć aktualną

16 Lumen Gentium, nr 59 mówi o tym, by zaznaczyć przywilej Maryi Dziewicy w Jej niepokalanym poczęciu. Dwa dekrety są trochę bardziej wymowne. Apostolicam actuositatem nr 7 zauważa, że ,ludzie skażeni grzechem pierworodnym, popadli w wiele błędów co do prawdziwego Boga, ludzkiej natury i zasad prawa moralnego..." Inter mirifica uczy, że w posługiwaniu się środkami przekazu społecznego należy się jak najściślej podporządkować ,zasadom moralnym, szczególnie w rzeczach wymagających należytego szacunku lub które mogłyby wzbudzić niezdrowe pożądanie w człowieku osłabionym przez grzech pierworodny".

17 Por. P. Guilly, itd. La culpabilité fondamentale, Coll. Recherches et Synthèses, Gembloux-Paris, Duculot, 1975.

18 Należałoby tutaj, raz jeszcze, odróżnić podstawowe stwierdzenia, postawy praktyczne i mentalności. Vaticanum II - Jana XXIII, Pawła VI i biskupów nie odwraca się w najmniejszym stopniu plecami do Trydentu czy Vaticanum I. Ale ,polityka", środowisko socjologiczne mogą ulec zmianie. Nie potrzeba weale zaprzeczać grzechowi pierworodnemu, ponownie zdefiniowanemu w Trydencie, by otworzyć się na dobro i autentyczne wartości ludzkie, nie trzeba podawać w wątpliwość tożsamości chrześcijańskiej, by przyjąć postawę dialogu raczej niż zamknięcia się. w getcie. Tak samo, Vaticanum II może zrewaloryzować posłannictwo biskupie i jego współ-odpowiedzialność nie podważając prymatu Piotra i jego następców. W rzeczywistości, wszystko odbywa się tak, jakby większość ludzi niezdolna była do dokonania uzupełniającej syntezy punktów widzenia. Dla pewnych osób, w obecnych czasach, to ,albo papież, albo biskupi”. „Bóg Zbawca albo człowiek bez grzechu". 
tendencję do opóźniania, możliwie najbardziej, chrztu małych dzieci. Bez wątpienia postęp medycyny w naszych krajach chroni je lepiej od niebezpieczeństwa przedwczesnej śmierci bez chrztu, ale czy nie ma w tym czegoś innego? Problem ten wypływa w licznych polemikach na ten temat. Chrzest jest tą samą rzeczywistością $\mathrm{w}$ dwu aspektach: przynosi $\mathrm{z}$ jednej strony ubóstwienie, adopcję boską, włączając dziecko w Chrystusa umarłego i zmartwychwstałego. Stąd drugi aspekt, wedle którego chrzest odbiera dziecku podobieństwo do Adama, starego człowieka, człowieka grzesznego, człowieka pełnego agresji wobec Boga, wobec innych, wobec samego siebie. W opóźnianiu - lub też odrzucaniu Chrztu dziecka - widnieją jasne powody, które wszyscy znają i na temat których można dyskutować na płaszczyźnie duszpasterskiej. Czy jednak jest pewne, że w podświadomości religijnej (lub niereligijnej) niektórych osób, nie ma innych motywacji głębokich i ukrytych? Zacytujmy: „zbawienie nie pochodzi od Chrystusa, ale od człowieka”, ,jaki sens ma zatarcie stanu grzechu u dziecka dopiero co narodzonego?”, ,istotą chrztu jest włączenie nowego członka do wspólnoty; akt ten ma mniej sensu w wypadku noworodka, niż później".

Ta meta-soborowa negacja w zarodku jest potwierdzana przez przedziwny rytuał chrztu, który pewna słynna parafia uniwersytecka chciała swego czasu uczynić modnym. Chrzest był tam zamieniony jedynie we włączenie do wspólnoty. Mógł dokonywać się etapami. Składał się z gestów coraz bardziej ujmujących, zależnie od wieku dziecka i jego rozwoju. Tam również znajdowała się perła, której przedziwne sformułowanie sprawiło, że zachowałem ją w pamięci: „Jeśli użyje się wody: unikać mówienia o zmazie do mycia; należy mówić o tryskającym źródle".

Czy mogę wspomnieć o innym przejawie tej samej tendencji? Myślę c deklaracjach słynnego teologa w wywiadzie dla tygodnika „Le Point" i TF 1 (program telewizyjny). Profesor tłumaczył tam, że grzechem pierworodnym jest kapitalizm. Przychodzimy na świat $\mathrm{w}$ tym systemie ucisku i jesteśmy weń włączeni. Bardzo trudno jest nam reagować przeciwko temu systemowi. Winno to stać się przedmiotem naszego osobistego zaangażowania.

\section{Odkupienie}

Nie chcę się rozwodzić nad skutkami tego negującego stanowiska. Ograniczę się do postawienia jednego pytania: Czy można mieć pewność, że trudności spotykane dzisiaj przy przedstawianiu Odkupienia i teologii, która go dotyczy, nie pochodzą, przynajmniej częściowo, ze zniesienia poprzedniego etapu historii zbawienia: zerwania ludzkości z Bogiem? Jak rozumieć zbawczy sens posłuszeństwa Chrystusa jeśli się neguje fakt 
i sens nieposłuszeństwa? Myślę jeszcze o Liście do Rzymian 5, 19: „Albowiem jak przez nieposłuszeństwo jednego człowieka wszyscy stali się grzesznikami, tak przez posłuszeństwo Jednego wszyscy staną się sprawiedliwymi" - To nie tylko List do Rzymian 5, wkłada się dzisiaj między nawiasy, lecz także opisy agonii Jezusa i List do Hebrajczyków. Jeśli, jak utrzymują liczni profesorowie, Chrystus nie wiedział, że ma umrzeć, w jaki sposób mógł uczynić ze swego posłuszeństwa Woli Ojca przejawiającej się w wydarzeniach, akt poddania i miłości, do którego ludzie nie byli zdolni: „Wszakże nie jak Ja chcę, ale jak Ty” (Mt 26, 39c)? Jak rozumieć nadto Odkupienie w perspektywie apostolskiej Listu do Hebrajczyków 12, 2: „qui gaudio sibi proposito, sustinuit crucem, confusione contempta"?

Nie popadajmy jednak w przesadny pesymizm. Kryzys grzechu pierworodnego i jego teologii, tak jak kryzys teorii Odkupienia, może być okazją do pewnego dobra. Czyż nie jesteśmy zaproszeni do przedstawiania dogmatu grzechu pierworodnego na jego miejscu w czasie historii zbawienia, w związku z Odkupieniem raczej, niż do czynienia zeń odrębnej prawdy? Czyż nie jest to okazja by lepiej uwidocznić dialektykę: człowiek-Chrystus-Trójca, grzech-łaska: ubi abundavit delictum, superabundavit gratia $(\mathrm{Rz} 5,20)$.

Czy nie tak postępuje Encyklika Redemptor Hominis, w rozdziałach 8 i 9? Przypomnijmy parę tych tekstów:

Przedstawiając odkupienie jak odnowione stworzenie, pierwsza encyklika Jana Pawła II mówi (nr 8):

„Redemptor mundi! W Nim objawiła się niejako na nowo ta podstawowa prawda o stworzeniu, którą Księga Rodzaju wyznaje, powtarzając po tylekroć: »widział Bóg, że było dobre... że było bardzo dobre«. Dobro ma swoje źródło w Mądrości i Miłości. W Jezusie Chrystusie świat widzialny, stworzony przez Boga dla człowieka - świat, który wraz z grzechem został poddany marności - odzyskuje na nowo swą pierwotną więź z samym Boskim źródłem Mądrości i Miłaści. Tak bowiem »Bóg umiłował świat, że Syna swego Jednorodzonego dał«. I tak jak w człowieku-Adamie ta więź została zerwana, tak w Człowieku-Chrystusie zostaje ona nawiązana na nowo. Czyż do nas ludzi XX-wieku nie przemawiają swą wstrząsającą wymową słowa Apostoła Narodów o stworzeniu, które »aż dotąd jęczy i wzdycha w bólach rodzenia « i »oczekuje objawienia się synów Bożych...", o stworzeniu, które "poddane jest marności«? Czyż olbrzymi, nie znany przedtem postęp, jako dokonał się w ciągu tego zwłaszcza stulecia w dziedzinie opanowania świata przez człowieka, nie ujawnia zarazem w stopniu przedtem nieznanym owego wielorakiego »poddania marności«"?. 
Nr 9 Redemptor Hominis mówi o „Boskim wymiarze tajemnicy Odkupienia" i między innymi oznajmia:

„Jezus-Chrystus - Syn Boga żywego, stał się naszym »pojednaniem u Ojca «. Że to On właśnie i On jeden uczynił zadość tej odwiecznej miłości, właśnie temu Ojcostwu, które od początku wyraziło się w stworzeniu świata, w obdarowaniu człowieka całym bogactwem tego stworzenia w uczynieniu go "niewiele mniejszym od istot niebieskich", bo stworzonym na obraz Boży i Bogu podobnego - a z kolei przecież Ojcostwu i miłości niejako odepchniętej przez człowieka wraz ze złamaniem pierwszego Przymierza i łamaniem tych dalszych, które Bóg wielokrotnie zawierał z ludźmi. Odkupienie świata - owa wstrząsająca tajemnica miłości, w której niejako na nowo »powtarza się« tajemnica stworzenia jest w swoim najgłębszym rdzeniu »usprawiedliwieniem " człowieka w jednym ludzkim Sercu: w Sercu Jednorodzonego Syna, ażeby mogło ono stawać się sprawiedliwością serc tylu ludzi, w tym Przedwiecznym Jednorodzonym Synu przybranych odwiecznie synów i wezwanych do Łaski, wezwanych do Miłości. Krzyż na Kalwarii, poprzez który Jezus Chrystus - Człowiek, Syn Maryi Dziewicy, przybrany Syn Józefa z Nazaretu - »odchodzi « $\mathrm{z}$ tego świata, jest równocześnie nowym otwarciem odwiecznego Ojcowstwa Boga, który w nim na nowo przybliża się do ludzkości, do każdego człowieka, obdarzając go tym trzykroć świętym »Duchem Prawdy «.

W tym objawieniu Ojca, w tym wylaniu Ducha Swiętego, które wyciskają jakby niezniszczalną pieczęć na Tajemnicy Odkupienia, tłumaczy się sens krzyża i śmierci Chrystusa. Bóg stworzenia objawia się jako Bóg odkupienia, jako Bóg, który jest wierny sobie samemu, wierny swej miłości do człowieka i do świata, wyrażonej w dniu stworzenia. A miłość Jego nie cofa się przed niczym, czego w Nim Samym domaga się sprawiedliwość. I dlatego Synowi swojemu nie przepuścił, ale Go »dla nas grzechem uczynił «. Jeśli »uczynił grzechem" absolutnie Bezgrzesznego, to dlatego, aby objawić miłość, która zawsze jest większa od całego stworzenia, która jest Nim samym, gdyż »Bóg jest miłością«. A nade wszystko jest Ona większa od grzechu, od słabości od "marności stworzenia«, potężniejsza od śmierci - stale gotowa dźwigać, przebaczać, stale gotowa wychodzić na spotkanie marnotrawnego dziecka, stale szukająca »objawienia się synów Bożych", którzy są wezwani do chwały. To objawienie miłości nazywa się również miłosierdziem. To objawienie miłości i miłosierdzia ma w dziejach człowieka jedną postać i jedno imię. Nazywa się: Jezus Chrystus". 


\section{TRANSFORMACJE NAUCZANIA SOBOROWEGO}

Miałem już okazję zasygnalizować wiele fałszerstw Vaticanum II, które znajduje się w meta-Soborze. Gaudium et Spes, $\mathrm{nr}$ 36, np. mówi o „słusznej autonomii rzeczy ziemskich" à propos badań nāukowych i instytucji, ale mówi także, w sposób przejrzystszy i dwukrotnie, że moralność nie może być autonomiczna. Co nie przeszkadza, by cały szereg „,moralistów" z meta-Soboru, pragnął znaleźć tu potwierdzenie przeciwnego punktu widzenia, czyli autonomię moralności ${ }^{19}$. Tutaj chciałbym przedstawić inny przykład tego typu ewolucji, która przeradza się w zniekształcenie i w pozycję sprzeczną z twierdzeniem, z którego wyszła. Jest to również przypadek „wspólnego kapłaństwa chrześcijan”.

\section{Wspólne kapłaństwo}

W Pierwszym Liście Św. Piotra 2, 9, natchniony autor, opierając się na Wj 19, 5-6 i Iz 43, 20-21 stosuje do Nowego Przymierza to, co było powiedziane o Starym: „Wy zaś jesteście wybranym plemieniem, królewskim kapłaństwem, narodem świętym, ludem [Bogu] na własność przeznaczonym, abyście ogłaszali dzieła potęgi Tego, który nas wezwał z ciemności do przedziwnego swojego światła". Ap 1, 6; 5, 10 również mówi, tyle że w sposób proroczy, o godności kapłańskiej i królewskiej.

Dla tych, którzy w latach 1925 - 35 byli młodzi, tematy te były pełne sensu. Akcja Katolicka, stworzona wówczas przez Piusa XI, ukazywała się nam jako ideał życia i apostolatu. Teksty te, o których nam wiele mówiono - po długim na ten temat milczeniu w Kościele Katolickim ${ }^{20}$ - uczyły nas, że nie jesteśmy już wyizolowanymi jednostkami, ale ludem. Nie tylko dzisiaj młodzież czuje się wyizolowana i szuka dróg porozumienia ${ }^{21}$. Z drugiej strony, ten lud pośród którego przyznawano nam miejsce uczestniczył w godności kapłańskiej, królewskiej i proroczej Chrystusa. Tak więc, Akcja Katolicka odnawiała w pewien sposób ten potrójny aspekt dzieła Chrystusa: proroctwo, królestwo, kapłaństwo. To właśnie tłumaczy dlaczego VI rozdział Lumen Gentium podkreśla tak

$19 \mathrm{Ph}$. Delhaye, Discerner le bien $d u$ mal, Cahiers du Livre, Chambray-les-Tours, 1979 , s. 62 nn.

20 Całe Sredniowiecze łacińskie powtarzało i komentowało te teksty bez wahania. Trudności zaczynają się gdy Luter uczynił z nich machinę wojenną przeciw kapłaństwu urzędowemu.

${ }_{21} \mathrm{Nie}$ usiłując dokonania kompletnej analizy, powiedziałbym tylko: trudność porozumienia i zrobienia sobie w życiu miejsca była taka sama wtedy jak dzisiaj. Natomiast, jest bardzo wyraźna różnica jeśli chodzi o inny punkt widzenia. Młodzież z roku 1930 starała się włączyć w świat dorosłych i uważała starców za potęgę. Pięćdziesiąt lat później, młodzi zapominają, że się postarzeli i chcą zbudować społeczeństwo młode, wciśnięte między dzieci i dorosłych. Jeśli chodzi o „starych", eliminuje się ich energicznie potrząsając palmą kookosową. 
silnie zarówno to rozróżnienie jak i charakter kapłański życia chrześcijańskiego ${ }^{22}$.

Znajdujemy tutaj złożony wpływ. Ks. prałat Gérard Philipps, główny redaktor Lumen Gentium, przez długie lata był kapelanem Akcji Katolickiej, wykładając równocześnie teologię, najpierw w Liège, potem w Louvain. Na tym uniwersytecie, wtedy jeszcze nie podzielonym, ten Flamand współpracował z Wallonem Cerfaux ${ }^{23}$, egzegetą Nowego Testamentu, który dawał podstawy biblijne, a szczególnie pawłowe do bardziej dynamicznej koncepcji Kościoła, w której świeccy mieli być ,zrehabilitowani", nie mając bynajmniej zamiaru dyskredytowania księży, przedstawicieli kapłaństwa urzędowego.

Cel, który postawił sobie redaktor Lumen Gentium, to przede wszystkim podkreślenie nadnaturalnej godności życia chrześcijańskiego, jak również, wedle wizji Piusa XI, związanego z naturą każdego chrześcijanina obowiązku obecności w apostolacie, dawania świadectwa Chrystusowi wobec ludzi. To również dotyczyło Akcji Katolickiej, która często odwoływała się do idei ,posłania” danego przez Hierarchię, co implikowało wspól-odpowiedzialność, współpracę, czyli udział w akcji hierarchicznej.

Wiele osób pamięta zapewne dwie wielkie tendencje dotyczące tego tematu. Pius XI zdefiniował Akcję Katolicką jako udział świeckich w hierarchicznym apostolacie. Niektórzy jednak uważali, że termin udział sięga zbyt daleko i że lepiej używać sformułowania „współpraca”. Ten zresztą drugi kierunek zwyciężył na początku pontyfikatu Piusa XII.

Niezależnie od używanego terminu, nie było mowy o tym by świeccy mogli marzyć o kapłaństwie, tego samego rodzaju i tej samej natury co kapłaństwo urzędowe. To właśnie Pius XII sformułował w dokumencie z 1954 r., który podejmuje Lumen Gentium, próbując ukazać jak współpracują dwa aspekty jedynego kapłaństwa Chrystusa, kapłaństwo księży i kapłaństwo wiernych ${ }^{24}$.

22 Nie mam wrażenia, żeby około 1930 roku, przyszło nam na myśl że my, świeccy, jesteśmy kapłanami... tak samo zresztą jak nie jesteśmy królami. Widzimy $\mathrm{w}$ tych tekstach potwierdzenie naszego związku z Chrystusem Królem (bardzo modne nabożeństwo w tamtych czasach) i z Chrystusem Kapłanem.

${ }^{23}$ Ks. prałat Lucien Cerfaux, ur. 1883, zmarł w Lourdes 11 sierpnia 1968. Szeroka(?) publiczność zna zwłaszcza jego: La théologie de l'Eglise suivant S. Paul; Le Christ dans la théologie de S. Paul; Le chrétien dans la théologie paulinienne wydane przez Cerf. Nota o Prałacie Cerfaux została właśnie opublikowana w Biographie Nationale Belge, t. 41, Supplément, t. 13, 1979, s. 95-110.

${ }^{24}$ Odwołuję się tutaj do najpopularniejszego przedstawienia problemu. Kiedy pogłębić temat, zauważa się, że może istnieć pewne niebezpieczeństwo w przeciwstawianiu tych dwu aspektów kapłaństwa Chrystusa, jeden z jednej strony, a drugi z przeciwnej. W ten sposób dochodzi się do wniosku, że księża nie uczestniczą już wcale w kapłaństwie powszechnym. Lepiej patrzeć na te sprawy w linii rozwojowej, jako swego rodzaju ,mutację”... ponieważ trudno nam myśleć nie odwołując się do wyobraźni przestrzennej. Swięcenia kapłańskie dają komuś, kkto uczestniczył w kapłaństwie powszechnym, status ontologiczny i nowy dynamizm. 
„Kapłaństwo zaś powszechne wiernych i kapłaństwo urzędowe, czyli hierarchiczne' choć różniq się istota a nie stopniem tylko, są sobie jednak wzajemnie przyporządkowane; jedno i drugie bowiem we właściwy sobie sposób uczestniczy w jednym kapłaństwie Chrystusowym. Kapłan urzędowy, dzięki władzy świętej, jaką się cieszy, kształci lud kapłański i kieruje nim, sprawuje w zastępstwie Chrystusa (in persona Christi) ofiarę eucharystyczną i składa ją Bogu w imieniu całego ludu; wierni zaś, na mocy swego królewskiego kapłaństwa, współdziałają w ofiarowaniu Eucharystii; pełnią też to kapłaństwo przez przyjmowanie sakramentów, modlitwę i dziękczynienie, świadectwo świętego życia, zaparcie się siebie i czynną miłość".

\section{Konsekwencje negatyw̋ne}

Widzimy więc bardzo wyraźny sens, jaki Lumen Gentium i jego redaktor chcieli oficjalnie nadać temu, co możnaby nazwać odnowieniem wspólnego kapłaństwa. Czyżby należało pójść dalej? Poza tym, że oznaczałoby to zniszczenie różnicy ontologicznej wyraźnie zaznaczonej w tekstach, pominięto by uwagę, jaką autorzy tych soborowych tekstów zwracali na możliwe dewiacje. Znalí błędy Reformatorów z XVI wieku związane z tym tematem: i nie mieli najmniejszego zamiaru ,sprotestantyzować" Kościoła Katolickiego. Wiedzieli również, że od czasu Soboru, istniała w Kościele pewna tendencja anty-urzędowa. Niech mi będzie wolno przypomnieć dwa zdarzenia dotyczące tego tematu.

Prałat Philipps poprosił mnie bym mu pomógł $\mathrm{w}$ sekretariacie, w opracowywaniu tego punktu doktryny ${ }^{25}$. Pewnego dnia zwierzył mi się ze swych obaw na temat zrealizowanych już, doświadczeń holenderskich. Chciano zredukować liczbę księżý, zorganizować parafie bez wyświęconych księży i powierzyć świeckim, wybranym przez wspólnotę, misję i władzę dawnych kapłanów. Implikowało to oczywiście transformację Eucharystii-ofiary w posiłek-wieczerzę, a także koniec spowiedzi. Prałat Philipps był jednak przekonany, że zdecydowanie i jasność tekstów Lumen Gentium zamkną drogę do podobnych deformacji ${ }^{26}$.

${ }^{25} \mathrm{Na}$ końcu drugiej sesji, byłem obarczony końcowym zredagowaniem obecnego rozdziału IV (podówczas III) o świeckich, wedle schematu: proroctwo, królestwo, kapłaństwo w Chrystusie i we wszystkich członkach Kościoła. Na początku trzeciej sesji, Sobór zdecydował dorzucić II rozdział (Lud Boży), który dotyczył zarazem Hierarchii i wszystkich katolików. Trzeba więc było wyjąć pewne teksty z dawnego rozdziału III, by umieścić je w rozdziale II i dostosować do nowego rozdziału IV. To właśnie tłumaczy równoległość wypowiedzi w obecnych rozdziałach II i IV, a także pewne powtórzenia.

${ }_{26} \mathrm{Czy}$ mogę sobie pozwolić na uwagę $\mathrm{z}$ historii i psychologii religii, obok aspektu doktrynalnego omówionego w tekście? Chwytamy tutaj na żywo optymizm (chwalebny sam w sobie, ale być może zubożony przez fakty?) niektórych wielkich osobistości Vaticanum II. Sądziły one, że posuwając się tak daleko jak się dało, 
W tym samym mniej więcej czasie, André Maria Charue, biskup Namur i wice-przewodniczący Soborowej Komisji Wiary i Moralności podzielił się ze mną podobnymi obawami. Obawy te pochodziły zresztą od jẹdnego z obserwatorów należących do jednej ze wspólnot kościoła zreformowanego. Pastor ten powiedział mi: „Popełniacie błąd wydając teksty o wspólnym kapłaństwie. Popełniliśmy tę samą omyłkę w XVI wieku i nigdy już nie udało nam się przywrócić poprzedniego stanu".

Niestety te pesymistyczne przewidywania spełniły się. Najpierw w sposób ukryty, a potem à propos poruszenia wokół Synodu z 1971 roku, w sposób otwarty, a nawet gwałtowny. Utworzyły się grupy księży-kontestatorów; domagali się oni zdecydowanie zniesienia celibatu dla kapłanów, zaprzeczając jednocześnie roli księdza jako pośrednika w Eucharystii. Stopniowo, prezentacja urzędu kapłana przypominała u nich jego obraz z czasu Reformy w XVI wieku. W niejednym kraju grupy świeckich głosiły te same idee i domagały się prawa konsekrowania Eucharystii. Artykuły w czasopismach, książki protestowały przeciw tradycyjnemu nauczaniu wiary o kapłaństwie, o sukcesji apostolskiej.

W licznych miejscach ukazały się te same schematy dotyczące przyszłości. Najpierw należy zorganizować parafie bez księdza. W ten sposób wyprzedza się i psychologicznie pogłębia kryzys powołań. Następne proponowane stadium to zdanie sobie sprawy, że parafie bez księdza skierowane są na brak Eucharystii i sakramentu pojednania. Trzecie stadium opiera się na „prawie ludu chrześcijańskiego do sakramentów”, na idei, mówiącej, że tam gdzie jest wspólnota, jest obowiązkowo Eucharystia ${ }^{27}$. Sugeruje się więc parafiom wybór jednego z członków wspólnoty do sprawowania tych posług. Oczywiście będzie nim ojciec rodziny, bez specjalnego przygotowania teologicznego ani duchowego. W ten sposób uda się ,odklerykalizować" Kościół Katolicki.

Dla czwartego stadium tej nowej dialektyki sprawowania posług wyrażono dwa poglądy. Najbardziej zaawansowani proponują, by wspólnota wkładała na wybranego ręce, tak jak to czynią kalwiniści i „,kongregacjonaliści". Inni, z większą rezerwą, mówią o wysłaniu wybranej osoby, by

przetną drogę wszystkim nadużyciom. „Polityka” Soboru Trydenckiego była natomiast pesymistyczna: „Niektórzy nadużyli kapłaństwa powszechnego, nie mówmy więc o tym". To samo optymistyczne stanowisko Soboru odnajdujemy u Pawła VI na temat modlitw eucharystycznych. Pozwolil, by ich zaproponowano 4, a potem $10 . .$. , by zapobiec mnożeniu się „dzikich kanonów”.

${ }_{27}$ Ten sam typ rozumowania, więcej niż uproszczony, był używany $w$ dziesięcioleciu 1970-1980 na rzecz uznania urzędów ustanowionych przez "Reformę" XVI wieku. Vaticanum II, mówi się, uznało, że te określenia chrześcijańskie są Kościołami (jest to zresztą fałszywe, ponieważ w odróżnieniu od Kościołów Wschodnich, które zachowały episkopat, zgrupowania te są tylko nazwane przez Vaticanum II „wspólnotami kościelnymi”). A przecież, mówią awangardziści, nie ma Kościoła bez eucharystii. A więc, zdają się wnioskować, że przełożeni tych wspólnot mają urząd ważny. Widać, jak zwiększa się ilość urzędów protestanckich i jak oczernia się urzędy katolickie, aby uzyskać coś w rodzaju średniej. 
włożył nań ręce biskup i prezbiterium. Mówią, że nie zyskuje się przynależności do kolegium bez publicznego rytu uznania.

\section{Prawdziwe pojęcia „Ludu Bożego”}

Dzisiaj, w 1980 roku, te ekstremalne teorie są może rzadziej głoszone, ale czytając pisma teologiczne, zdajemy sobie sprawę, że prace podkopujące szczególny urząd hierarchiczny trwają.

Jest więc rzeczą konieczną, także tutaj, przywrócenie autentycznej myśli Soboru na temat „ludu Bożego”, na temat dwu kapłaństw. Trzeba to pokazać na przykładzie tekstów; Vaticanum II nie wahało się nad rozróżnieniem Kościoła hierarchicznego, apostolskiego i Kościoła Ludu Bożego. Nauczało o dwu aspektach Kościoła: jest on zgromadzeniem wiernych Chrystusa, jest wspólnotą. A jednak nie jest jednorodny, ponieważ Chrystus i Apostołowie nadali mu struktury. Lud Boży kierowany jest przez kapłanów, którzy mają potrójną exousia Chrystusa: nauczanie, troskę pasterską i moc uświęcania poprzez Chrzest i inne sakramenty (por. Mt 28, 19).

Po przeciwstawieniu się Pawła VI destrukcyjnym tezom, ofensywa Jana Pawła II jest znakiem nadziei w tej sprawie. Opierając się na Vaticanum II, Ojciec Swięty napisał swoje dwa „Listy na Wielki Czwartek" o kapłaństwie urzędowym i ofierze eucharystycznej.

Chcąc zakończyć ten rozdział, spróbuję pokazać tu, jak dobro məże wyniknąć ze zła. Posługi diakonów, księży i biskupów, zostaną ponownie przemyślane i lepiej określone pod koniec tego kryzysu. Ukażą się one bardziej jako służba a mniej jako władza, ponieważ władza tutaj podporządkowana jest służbie: sicut qui ministrat (Łk 22, 27). Tam, gdzie to jest konieczne, przyciszy się ducha panowania... który, w gruncie rzeczy, jest odwieczną pokusą dla osób obarczonych odpowiedzialnością lub tylko pragnących postępować dobrze. Świeccy, zgodnie z duchem Akcji Katolickiej, poczują się naprawdę „w domu”, domu Bożym. Spełniać będą swoje odpowiedzialne zadania we współpracy z kapłanami i biskupami. A szczególnie wszyscy wierni poczują się ludem, grupą po trosze wszędzie obecną $\mathrm{w}$ autentycznych braterskich wspólnotach. Z tego właśnie kryzysu Kościół winien wyciągnąc ć. wnioski na temat prawdziwej natury ludu chrześcijańskiego, ludu świętego, kapłańskiego, królewskiego, na skutek intymnego zjednoczenia z Bogiem poprzez posługi święte.

\section{DOKTRYNALNE I DUSZPASTERSKIE ZACHWIANIE RÓWNOWAGI}

Można by również znaleźć przejaw meta-Soboru w pewnych zakłóceniach równowagi w dziedzinie doktryny i duszpasterstwa. Chodzi tu 
mniej o błędy formalne czy negacje, a raczej o uprzywilejowanie pewnych aspektów ,wiary, którą wyznajemy i przeżywamy” kosztem innych aspektów chrześcijaństwa.

Od piętnastu lat mówi się nam bez przerwy o ruchu wahadłowym jako prawie myśli i działania. Ponieważ nazbyt podkreślano pewne aspekty wiary i życia chrześcijańskiego, trzeba było zgodzić się na to, by z kolei inne aspekty zostały uwypuklone. Jest to nieuniknione, gdyż chodzi o ludzi, którzy nie umieją myśleć równocześnie o wszystkim i których porywają ruchy historii. Przyszedł czas, by dowiedzieć się, czy wahadło nie zostało sztucznie zatrzymane po jednej stronie i czy wykład wiary i teologii nie powinien łagodnie ustalić się w centrum.

\section{Krzyż i Zmartwychwstanie}

Przychodzi mi na myśl przykład tego typu ewolucji: stosunki między Kościołem a światem. Przed Soborem, jedynym zaleceniem była opozycja i walka. Po Soborze, mówi się wyłącznie o dialogu, o zgodzie, o asymilacji... tak dalece, że niektórzy zastanawiają się, czy nie chodzi po prostu o kapitulację, poddanie się, wchłonięcie. Nie będę tutaj mówił na ten temat: nowa książka O. de Lubac, cytowana już wyżej, powiedziała wszystko o tym nowym aspekcie problemu stosunków łaski i natury, Boga i człowieka. Miałem sposobność do mówienia na ten temat gdzie indziej ${ }^{28}$, wolałbym tutaj poruszyć różnorodne aspekty tajemnicy paschalnej, a szczególnie dialektykę Krzyża i Zmartwychwstania. Być może mógłbym zacytować moje doświadczenia na temat ewolucji mentalności w ciągu ostatnich pięćdziesięciu lat. Jest rzeczą oczywistą, że w rzeczywistości misterium Zbawiciela Krzyż i Zmartwychwstanie są nierozerwalnie złączone i również ważne: Christus traditus est propter delicta nostra et resurrexit propter justificationem nostram pisze Sw. Pawel (Rz 4, 24-25). Co nie przeszkadza temu, że w ciągu pięćdziesięciu lat, poszczególne miejsca dawane Krzyżowi i Zmartwychwstaniu zmieniały się wielokrotnie. W 1930 r. umieszczono w nawiasach Żmartwychwstanie, a teraz zdaje się, że meta-Sobór czyni to samo z Krzyżem.

Ruch liturgiczny ${ }^{29}$ pozwolił młodym lat 30-tych odkryć na nowo całe

28 Por. Ph. Delhaye, Droits de l'homme et morale chrétienne, in Studia Montis Regii, 1965, s. 137-167; Le dialogue de l'Eglise et du monde, Coll. Réponses chrétiennes, Gembloux, 1968, s. 160; Discerner le bien du mal, Chambray-les-Tours, 1979, s. 171 (por. Esprit et Vie 1980, s. 480).

${ }_{29} \mathrm{~W}$ perspektywie dość empirycznej rozróżniłbym następujące stadia: pierwszy ruch liturgiczny opierał. się na Dom Guéranger i Solesmes. Trwał aż do 1914 r. Po pierwszej wojnie światowej rozszerzył się na wszystkie klasztory benedyktyńskie, a dla języka francuskiego centrum jego jest Mont-César de Louvain (obecnie Kaisersberg van Leuven), który ożywia tygodnie liturgiczne wędrowne. Po drugiej wojnie światowej trzeci ruch liturgiczny rozwija się w Paryżu wokół Centre de Pastorale Liturgique. Wypowiada się poprzez swoje pismo: Maison-Dieu. Po Sobo- 
znaczenie Zmartwychwstania. Możemy znaleźć potwierdzenie tego w tekstach pawłowych umieszczonych $\mathrm{w}$ mszale i w brewiarzu; z radością odkrywamy przepych liturgii Wschodu, w tym szczególnym momencie roku chrześcijańskiego. Czujemy, że niedziela, w rycie łacińskim straciła swój sens cotygodniowej celebracji Zmartwychwstania, i stała się nieokreślonym dniem kultu.

Niezadowolenie i uczucie zawodu rozciąga się zresztą na inne fakty. W owych czasach studenci teologii, na uczelniach świeckich lub w seminariach, słyszeli z ust profesorów, bardzo poważny traktat o Zmartwychwstaniu. Ale często traktat ten był przedstawiany jako zwykły dodatek do De Verbo Incarnato. Istniała tendencja do skupiania całej wartości zbawczej ofiary Jezusa na Wielkim Piątku gdyż, jak mówiono, Chrystus nie mógł pełnić funkcji zasługującej po śmierci ludzkiej. W czym więc Zmartwychwstanie mogło dotyczyć naszego zbawienia? Pamiętam, że szukałem odpowiedzi na to pytanie do rozważań na dzień Wielkiejnocy roku 1932. Wszystko, co udało mi się znaleźć, to dziełko słynnego i zasłużonego M. Tanquerey'a. Dla niego Zmartwychwstanie Jezusa odkupiało nas $\mathrm{w}$ takim sensie, że było przykładową przyczyną przyszłego zmartwychwstania naszych ciał. To prawda, ale nieco przykrótka na moje potrzeby. Uroczyste kazanie ówczesnej Mszy św. Wielkanocnej zazwyczaj obracało się wokół apologetycznych dowodów zmartwychwstania ciała Chrystusa. To był „,pusty grób”, jak żartował wtedy O. Hilaire Duesberg, który w podobnych okolicznościach podkreślał. znaczenie życia Chrystusa przekazywanego wszystkim ochrzczonym. Już parę lat wcześniej O. Marmion nauczył nas niemało na ten temat ${ }^{30}$.

Trzeba było dwudziestu czy trzydziestu lat, by trzeci ruch liturgiczny uzyskał odnowę święta Wielkiejnocy przez Piusa XII i Vaticanum II. Już na pierwszych stronach Konstytucja Liturgiczna Sacrosactum Concilium (nr 5) podkreśla pierwszorzędne znaczenie Odkupienia przeżywanego w tajemnicy paschalnej: śmierci i Zmartwychwstania ${ }^{31}$. Zapamię-

rze, dorchodzi do głosu nowa mutacja: uprawia się post-sobór, para-sobór, a niekiedy także meta-sobór.

30 P.onieważ ulegam rodzajowi ,wyznań z przeszłości” stwierdzam w mojej bibliografii stałość i ewolucję w stosunku do tego tematu. Pod pseudonimem Jean Daley (klerycy nie mieli prawa publikacji) zredagowałem studium Le dimanche chrétien w La Cité Chrétienne (kierowana przez Jacquesa Leclercq): Le dimanche chrétien (1933, $\mathrm{nr}$ 163-164, s. 1104-1114). W Lille przepracowalem temat niedzieli jako cotygodniowej Wielkanocy $\mathrm{z}$ pewnym studentem. To doprowadziło do $\mathrm{Ph}$. Delhaye i J. Lecat, Dimanche et sabbat w Mélanges des Sciences Religieuses, Lille, 1966 , s. 1-14, 73-94. Artykuly te przedrukowano w broszurze Etudes Religieuses, La Pensé Catholique, Bruxelles, s. 160 pod tytułem La messe du samedi soir. W międzyczasie próbowałem zorientować się lepiej w ,teologii Wielkanocy" w 30-stronicowym wstępie do książki przyjaciela: R. Wasselynck, S. Grégoire le Grand, Homélies pour les dimanches du cycle de Pâques, Coll. Les Ecrits des Saints, Namur, Ed. du Solleil Levant, 1962.

31 Konkordacja sygnalizuje 30-krotne użycie słowa Crux i 29 dla Pascha. A pro- 
tajmy przynajmniej te słowa, które dotyczą tajemnicy paschalnej w całej jej rozciągłości. Po omówieniu Odkupienia Konstytucja Sacrosactum Concilium dodaje:

„Tego zaś dzieła Odkupienia ludzi i doskonałego uwielbienia Boga, które zapowiadały wielkie sprawy Boże spełnione wśród ludu Starego Testamentu, dokonał Chrystus Pan głównie przez paschalne misterium swojej błogosławionej Męki, Zmartwychwstania i chwalebnego Wniebowstąpienia. Przez to misterium »umierając pokonał naszą śmierć, a zmartwychwstając odnowił życie«. Albowiem z boku umierającego na krzyżu Chrystusa zrodził się przedziwny sakrament całego Kościoła”.

Każda Msza święta jest również wspomnieniem ofiary Krzyża i Zmartwychwstania, tak jak uczy nr 47 tego samego dokumentu:

„Zbawiciel nasz podczas Ostatniej Wieczerzy, tej nocy, kiedy został wydany, ustanowił Eucharystyczną Ofiarę Ciała i Krwi swojej, aby w niej na całe wieki, aż do swego przyjścia, utrwalić Ofiarę Krzyża i tak umiłowanej Oblubienicy Kościołowi powierzyć pamiątkę swej Męki i Zmartwychwstania: sakrament miłosierdzia, znak jedności, węzeł miłości, ucztę paschalną, »w której pożywamy Chrystusa, w której dusza napełnia się łaską i otrzymuje zadatek przyszłej chwały «".

Jeśli chodzi o niedzielę, przestała ulegać zbieżności i konkurencji świąt świętych i przywrócono jej własną wartość. Temu właśnie tematowi poświęcony jest $\mathrm{nr} 106$ :

,Zgodnie z tradycją apostolską, która wywodzi się od samego dnia Zmartwychwstania Chrystusa, Kościół obchodzi misterium paschalne w każdy siódmy dzień, który słusznie nazywany jest dniem Pańskim albo niedzielą. W tym bowiem dniu wierni powinni schodzić się razem dla słuchania słowa Bożego i uczestniczenia w Eucharystii, aby tak wspominać Mękę, Zmartwychwstanie i chwałę Pana Jezusa i składać dziękczynienie Bogu, który ich »odrodził przez Zmartwychwstanie Jezusa Chrystusa dla nadziei żywej« (1 P 1, 3). Niedziela zatem jest wśród świąt najstarszym i pierwszym dniem świątecznym, który należy tak przedstawić i wpoić w pobożność wiernych, aby stał się również dniem radości i odpoczynku od pracy. Ponieważ niedziela jest podstawą i rdzeniem całego roku liturgicznego, nie należy jej przesłaniać innymi obchodami, jeżeli nie są rzeczywiście bardzo ważne”.

Czy ośmielono by się powiedzieć, że meta-Sobór zdołał utrzymać tę samą równowagę między Krzyżem a Zmartwychwstaniem, cierpieniem i radością? Czy nie było tam - bez gry słów - prawdziwego zaćmienia

pos tajemnicy Krzyża w Vaticanum II, niech mi będzie wolno zasygnalizować opracowanie, które opublikowałem w 1976 r. w Amitiés Sacerdotales i którego tłumaczenie na włoski zostało wydane w broszurze: Il mistero della Croce nei testi di Vaticano II, Milan, 1976. Mamy nadzieję wydania jej drugiej edycji francuskiej poszerzonej. 
Krzyża Jezusowego i naszego udziału w jego cierpieniach? Dzisiaj chrystianizm przedstawiany jest bardzo często jako święto i ostateczne kryterium moralne zdaje się czasem zlewać z natychmiastowym rozkwitem. Ilu teologów unika mówienia o zbawczej męce Chrystusa? Iluż z nich posuwa się aż do twierdzenia, że Chrystus nie wiedział że ma umrzeć, a zwłaszcza 'umrzeć za nas' jak to głosi pierwotny kerygmat! Hans Küng, który jest tutaj przywódcą licznej grupy zwolenników sądzi, że Jezus uważał natychmiastowe przywrócenie Królestwa niebieskiego za bardzo bliskie. Słowa „Deus meus, Deus meus quare dereliquisti me...” wzięte są W sensie radykalnym. „On (Chrystus) umiera opuszczony zarówno przez ludzi jak i przez Boga" ${ }^{32}$. Zaprzecza się autentyczności słów Jezusa wypowiedzianych w czasie Ostatniej Wieczerzy; szkoła ta uważa jako jedynie historyczną zapowiedź Jezusa, że nie będzie już pił owocu z winnicy wraz ze swoimi. W takich warunkach, oczywiście, jest bardzo trudno znaleźć jakiś nowy traktat o Odkupieniu ${ }^{33}$.

\section{Pobożność i moralność}

Zażenowane milczenie jest równie poważne w dziedzinie pobożności i moralności. Tajemnica Krzyża zdawała się tak zdeprecjonowana parę lat temu, że uznano za konieczne zorganizowanie w Rzymie w 1975 roku specjalnego Kongresu poświęconego temu tematowi ${ }^{34}$. Rozejrzyjmy się zresztą wokół siebie i pomyślmy, co stało się z nabożeństwem Drogi Krzyżowej. W ilu „miejscach kultowych” post- czy meta-soborowych znajdzie się choćby architektoniczny ślad 14 stacji?

W moralności, ten brak Krzyża objawił się zaniechaniem wysiłku i cierpienia.

Oczywiście nie należy wychwalać cierpienia dla niego samego, jak to czynił jansenizm i pewien „doloryzm”. Czyż można jednak dokonać w życiu czegoś właściwego bez trudu, wysiłku, „,ierpienia”? Już św. Paweł porównywał wolę chrześcijańską do wysiłków sportowców. W czasie „Tour de France”, słyszymy niejednokrotnie, że zawodnik nie może się potwierdzić jeżeli „nie umie cierpieć”. Dla chrześcijanina, nie chodzi tylko o cierpienie na płaszczyźnie naturalnej, jak to czynią stoicy, ale

32 H. Küng, Vingt propositions de „Etre chrétien”, Paris, Le Seuil 1979, s. 44. Czy wolno mi przypomnieć moje studium: "L'affaire de Hans Küng” w Esprit et Vie, 1980 , s. 218-221, 241-248, 257-269, 273-283. Można zobaczyć zwłaszcza H. Schurmann, Jésus devant sa mort, „Lectio divina”, 1977.

${ }^{33}$ Zauważmy szczęśliwy wyjątek, J. Galot, Le problème christologique actuel, Chambray-les-Tours, Cahiers du Livre, 1979, s. 109. O. Galot napisał po francusku trzy tomy chrystologii... ale musiał je wydać po włosku. Dzięki Bogu odważni redaktiorzy z Cahiers du Livre dadzą nam niebawem tekst francuski.

${ }^{34} \mathrm{La}$ Sapienza della croce. Atti del congresso, październik 1975 . Niech mi będzie wolno zasygnalizować mój wkład, t. 1, 1976, s. 332-344. 
o cierpienie z Chrystusem. Męka Pana, którą okrucieństwo ludzi uczyniło szczególnie bolesną, ma znaczenie poprzez posłuszeństwo i poprzez miłość. Odpowiedź Pana Jezusa na kuszenie w Getsemani, pokazuje że Chrystus przyjmuje kielich, by spełniła się wola Boga, a nie Jego własna wola. III Sobór Konstantynopolitański $(680-681)^{35}$ powie, że ludzka wola Chrystusa zjednoczyła się z wolą boską dla zbawienia ludzi. To wola miłości, a nie gniewu, wola daru na rzecz bliźniego, ofiary dla bliźniego. W tej właśnie woli ból znajduje sens, którego sam w sobie nie posiada. Dodaje doń zresztą dowód autentycziości i wiarygodności. Zbyt łatwo jest kochać Boga i być mu posłusznym, kiedy Jego wola jest idealnie zgodna z naszą. Stąd właśnie bierze się zasadnicza utrata sensu Krzyża. Nie prosimy już Boga, by czynił swoją wolę jak uczy nas „Ojcze Nasz”, ale by Bóg i Kościół czynili naszą wolę ${ }^{36}$.

\section{Wiara i Chrystologia}

Tu także, jak sądzę, znajdujemy radykalne odwrócenie, jakim jest meta-Sobór.

W dziedzinie Wiary, zaciemnia się ideę Objawienia, podważa się w sposób zasaániczy natchnienie Pisma czy nieomylność Kościoła wyrażającą się w nauce papieża.

Dlaczego? W imię czego? Ponieważ dane te nie odpowiadają znakom czasu (lekkomyślnie mylonym $\mathrm{z}$ ankietami socjologicznymi) ani naukom humanistycznym. Oczywiście, te ostatnie mogą i winny być włączone w wiarę chrześcijańską, wyznawaną i przeżywaną. Ale na sposób instrumentu, dodatku, tak jak to uczynił św. Tomasz i inni scholastycy z filozofią grecką. Dziś nie chodzi już o uzupełnianie, objaśnianie Objawienia poprzez nauki humanistyczne, ale o zastąpienie go przez nie ${ }^{37}$.

35 Zob. Denzinger-Sch. nr 550-559, Dumeige, nr 359-360.

36 Dewiacja przy lekturze Błogosławieństw może nawet dojść do głosu, jak zanotował to O. Carré OP., w uroczystej sesji Stulecia Fakultetów Katolickich w Lille. Wiele narzeczonych, mówił ten dawny kaznodzieja z Notre-Dame, rozmawia ze mną na temat tekstów liturgicznych, które mają być czytane w czasie ich ślubnej Mszy św. Wielu z mich wybiera najpierw obietnicę szczęścia (jakże prawowitą i uzasadnioną) błogosławieństw. Ale przy lekturze uważniejszej, prawie zawsze chcieliby coś opuścić: trudne chwile do przejścia zanim osiągnie się szczęśliwość. O. Carré dorzucał: w moralności chrześcijańskiej musi istnieć odwrócenie, próg do przekroczenia, który nie jest ani łatwy ani radosny.

37 Sw. Tomasz i większość scholastyków z XII wieku wprowadzają filozofów $\mathrm{w}$ podziw, który jak w niektórych dziełach Abelarda († 1141) doszedł do zastąpienia Ewangelii Platonem i Arystotelesem. Chodziło wtedy o nauki humanistyczne, które zastąpiły Objawienie zamiast się nim posługiwać. Nihil novi sub sole! Abelard doszedł w niektórych swolich pismach do tego, że nie widział już, jak tajemnica paschalna może być ofiarą bosko-ludzką, ontologicznie ważną dla wszystkich ludzi. Umniejsza on więc wpływ Odkupienia do zwykłego przykładu psychologicznego, który chrześcijanie winni naśladować. Czyż nie taka jest pozycja niektórych naszych współczesnych: Chrystus jest czlowiekiem, który zrozumial, że rzeczywistość moralna polega na istnieniu dla drugich, na dawaniu siebie drugim? Można by cytować zarówno H. Künga, jak i Bruno Ribesa. 
Tak więc, Odkupienie, poprzez Krzyż i Zmartwychwstanie jest całkowicie ,zlikwidowane”. Chrystus jest co najwyżej przykładem bycia dla drugich, którym dzisiejszy człowiek może się inspirować tak jak innymi wielkimi ludźmi. W ten sposób można posunąć się jeszcze dalej. Konstruuje się rzekome chrystologie zastanawiając się, kim winien być Chrystus, by zostać wybawcą uciśnionych w naszych czasach. Od Księgi Rodzaju poprzez Ewangelię i aż do Sw. Pawła, trudność jest zdecydowanie ta sama: poza Bogiem nie ma dla ludzi zbawienia, ale ludzie nie chcą być zbawieni przez Chrystusa; chcą się zbawiać sami, całkiem sami.

W moralności, ten antropocentryzm może doprowadzić do dwu bardzo różnych stanowisk opisanych w Ewangelii: postawy faryzeusza i postawy grzesznika. Faryzeusze (Łk 18,9) łudzili się, że sami przez się są sprawiedliwi. Dlatego właśnie nie byli w stanie słuchać Jezusa. Chrystus przynosił im zbawienie poprzez łaskę i prosił by połączyli swe wysiłki z tą łaską. Dlatego nauka Sw. Pawła jest tak cenna w moralności. W imię swojego doświadczenia i swojego apostolskiego charyzmatu pokazuje nawrócenie faryzeusza: nie usiłuje już usprawiedliwiać się; chce współdziałać z łaską, odpowiadać łasce, Duchowi i sprawić, by Duch w nim wydał owoce (Ga 5, 22; 1 Kor 15, 10). Pokusa dzisiejszego człowieka nie zmierza w stronę faryzeizmu, chociaż po zniszczeniu tradycyjnej moralności, jesteśmy świadkami narodzin praktyki niezwykle pewnej siebie i jeszcze bardziej ekskluzywnej. Jednakże tendencja generalna zmierza raczej do poprzestania na kondycji grzesznika, nawet za cenę twierdzenia, że taki właśnie jest los człowieka i nie zatrzymywania się na pojęciu grzechu.

W niezliczonych cytatach, które usłyszeliśmy na temat dialogu między Chrystusem a kobietą cudzołożną, zawsze padały słowa: „I ja ciebie nie potępiam" ${ }^{38}$, ale nigdy, przenigdy nie słyszeliśmy, by wymieniano co następuje: „idź i nie grzesz więcej”.

Ludzie nigdy nie lubili uznawać swoich błędów. By się o tym przekonać wystarczy przeanalizować z bliska jak wykręcają się ci, którzy są zmuszeni przepraszać. Dzisiaj zjawisko to prawdopodobnie posunęło się dalej.

Tłumaczy ono aktualny nacisk na zniesienie indywidualnej spowiedzi i zastąpienie jej kolektywnym rozgrzeszeniem. Ale jednocześnie, i to $\mathrm{w}$ o wiele głębszym stopniu, następuje ogromna eksplozja hedonizmu. Wydaje się, że Rabelais wygrał przy pomocy swojej reguły z Thélème: „Rób co chcesz".

${ }^{38}$ Chrystus może widzieć usprawiedliwienia subiektywne, okoliczności łagodzące u kobiety. Może również, jako prawodawca Nowego Testamentu, znieść przepis dawnego Prawa nakazującego ukamienowánie cudzołożnej kobiety. 
Sobór, wzięty w swojej autentyczności, pomoże nam powtórzyć z przekonaniem za św. Pawłem: „Nos autem oportet gloriari in cruce Domini nostri Iesu Christi" (Ga 6, 14).

\section{FAESZYWE SLOGANY META-SOBORU}

\section{Wolność religijna}

Również fałszywe slogany mogą być przejawem meta-Soboru. Weźmy na przykład: wolność religijnq. Spróbujmy uchwycić zawartość wolności religijnej na płaszezyźnie meta-soboru. Doświadczenia są tu odrębne i różne, ale w gruncie rzeczy precyzują się w miarę sumowania ich. Te fałszywe interpretacje zgadzają się o wiele łatwiej niżby się mogło wydawać.

- Najbardziej rozpowszechnionym sloganem jest ten: głoszenie wolności religijnej oznacza stwierdzenie, że wszystkie religie mają tę samą wartość. A co za tym idzie, nie widać już prawie wcale - poza pozytywnym rozkazem Chrystusa, nie wyjaśnionym zresztą - nie widać już wcale dlaczego należy głosić Ewangelię. Czy można zapomnieć wahania i trudności przy formułowaniu tekstu końcowego Synodu w roku 1974? Zgromadzenie odrzuciło tekst arcybiskupa Wojtyły, który przynosił teologię ewangelizacji opartą na dogmatach Objawienia i Odkupienia. Paweł VI zmuszony był ująć sprawę w swoje ręce publikując osobiście Evangelii Nuntiandi.

- W innej dziedzinie, slogan o wolności religijnej zbliżył się do nowoczesnego żądania. sformułowanego przez Nietzschego: to świadomość tworzy wartości i ich wymagania. Bóg umarł. Ludzie nie wiedzą o tym, tak jak więźniowie, którzy nie wiedzą o zgonie swego strażnika. Ale fakt niemniej istnieje. Więźniowie mogą odejść. Ludzie są całkowicie wolni. Muszą świadomie tworzyć tabelę wartości, wychodząc przede wszystkim i zespołowo od najpilniejszych potrzeb. Jesteśmy poza uczciwym dobrem i poza złem. Istnieje tylko to co jest pożyteczne, to wszystko.

- Niektórzy politycy głosili wolność religijną, która nie zważa na granice, jakie Sobór bardzo wyraźnie wskazal. Te granice to: prawa innych ludzi, wspólne dobro, moralność publiczna. Doszliśmy więc do pewnego „zaawansowanego liberalizmu”, który znosi w dziedzinie praw hamulce nakładane ongiś na przerywanie ciąży, cudzołóstwo, przemoc itd.

- Inną ekstrapolacją było przeniesienie wolności religijnej ogłoszonej w dziedzinie religii przeciw presjom politycznym, na wolność, której stale ktoś domaga się wewnątrz Kościoła, przeciw jakiejkolwiek interwencji zwyczajnej czy nadzwyczajnej Magisterium. 
Dwa miliony Francuzów zadeklarowało moralne przystąpienie do protestantyzmu z racji właśnie tego „liberalizmu”. Protestanci francuscy podwoili w ten sposób swój stan liczebny.

Bez żadnego wątpienia, chodzi tu jedynie o przynależność tendencyjną, ale fakt pozostaje faktem. W powodach podanych przez te osoby znajdujemy protest przeciw moralności Kościoła, domaganie się antykoncepcji bez żadnego rozróżnienia, przerywania ciąży, rozwodów, powtórnego małżeństwa rozwiedzionych, braku jakiejkolwiek władzy doktrynalnej.

Czyż nie słyszeliśmy ekwiwalentu tego wszystkiego od 1968 czy 1970 r.? Przyzywano wolności religijnej przeciw dyrektywom Kościoła w dziedzinie moralności, a zwłaszcza w dziedzinie moralności małżeństwa. Aby dopełnić miary René Simon i Pierre de Locht oznajmili już wtedy, że życie moralne jest rzeczywistością doczesną, która zdobyła sobie prawowitą autonomię w stosunku do Kościoła.

\section{Nauczanie soborowe}

Jeśli „przeżycie” czy „czucie” wolności religijnej jest takie właśnie, to jakże się dziwić, że „integryści” oskarżyli Vaticanum II i Dignitatis Humanae, żè są źródłami większości obecnych schorzeń.

Nie trudno jest wykazać, że ich analiza jest fałszywa. Trzeba przywrócić autentyczną doktrynę Vaticanum II na ten temat. Przypomnę w skrócie parę jej punktów ${ }^{39}$.

- Problem wolności religijnej nie był badany przez Vaticanum II na płaszczyźnie ontologicznej, tak jak to czyniono w XIX wieku. Sobór usytuował się na płaszczyźnie personalistycznej. Na to ktoś powie: błąd, tak samo jak zło nie ma żadnych praw, natomiast osoby będące w błędzie mogą mieć prawa, zwłaszcza w stosunku do władzy politycznej, która nie posiada jurysdykcji w sprawach religii.

- Prawa osoby ludzkiej implikują również obowiązki, a w szczególności obowiązek poszukiwania prawdy, a przede wszystkim prawdy religijnej. Ale przecież niełatwo tę prawdę znaleźć, trzeba przyjąć i tolerować pomyłki, jeżeli nie szkodzą one porządkowi publicznemu i prawom innych osób.

- Akt religijny a zwłaszcza związek $\mathrm{z}$ wiarą, traci cały swój sens jeśli nie płynie $\mathrm{z}$ osobistego przekonania. Nie może więc być brutalnie narzucony z zewnątrz, na przykład przez Państwo. Trzeba jednak wziąć

${ }^{39}$ Por. R. Coste, Théologie de la liberté religieuse, Liberté de conscience. Liberté de religion. Coll. Recherches et Synthèses, Gembloux-Paris, Duculot, 1969, s. XXVIII - 516. Ph. Delhaye, Liberté religieuse iw Catholicisme, t. 7, col 675-689. 
pod uwage pośrednictwo rodziny, środowisko kształceniowe, religię ludową.

- Reasumując, najważniejsza zmiana przyniesiona przez Dignitatis Humanae dotyczy roli Państwa. Jego moralizatọskie działanie wyraźnie zmalało na płaszczyźnie poszczególnych osób, dorosłych. Zredukowało się do porządku publicznego i nie dotyczy júż indywidualnego życia. $\mathrm{Na}$ tej płaszczyźnie Sobór obdarza o wiele większym zaufaniem działanie katolików i ich duszpasterzy, tak samo zresztą jak odwołuje się do poczucia odpowiedzialności wszystkich obywateli.

\section{JAKIE SRODKI ZARADCZE NALEŻY ZASTOSOWAC W STOSUNKU DO DEWIACJI META-SOBORU}

\section{Ożywić ponownie Sobór?}

Jeśli meta-Sobór jest naprawdę deformacją Soboru, to jedynym stanowiskiem jakie należy w stosunku do niego zająć jest powrót do autentyczności w studiowaniu Soboru i prawomocnych konsekwencji, które zeń wyciągnie Kościół poprzez post-Sobór.

Należy uniknąć podwójnego błędu:

a) Ubolewać z powodu zaistnienia Soboru, starać się go wymazać by powrócić do okresu przedsoborowego. Takie jest stanowisko abpa Marcela Lefebvre w Ecône. Jest w tym zresztą pewna zasadnicza iluzja: iluzja zatrzymania ewolucji życia. Problemy teologii, kultury, ekonomii, „,świata” narzuciłyby się tak czy owak „Kościołowi Piusa XII”. Kościół ten nie rozwiązałby ich lepiej, a szok byłby bez wątpienia większy i trudniejszy do zniesienia.

b) Z drugiej strony trzeba unikać, by tendencje awangardowe, które przejawiły się w czasie Soboru i potem, rozwijały się same dla siebie i bez umiaru.

Oczywiście istniały napięcia i rozbieżności. Niektórym z nich Sobór otworzył perspektywy, których nie dało się zrealizować. Ale po tych ogromnych wspólnych poszukiwaniach, stworzono syntezy, próby koegzystencji pokojowej, pewien pluralizm.

Błędem byłoby pozwolić, by w sposób unilateralny rozwijały się różne tendencje odśrodkowe, nieautentyczne, pozbywając się przeciwwagi, którą umieściła tam mądrość Soboru.

Przypadek cytowany przez $O$. de Lubaca jest bardzo znamienny ${ }^{40}$. Od 1963 r. O. Schillebeeckx dyktuje Soborowi, co powinienby zrobić, by nie zawieść świata: zresorbować to co boskie w tym co ludzkie, tak by

${ }^{40} \mathrm{H}$. de Lubac, Petite catéchèse sur nature et grâce, Coll. Communio, Paris, Fayard, s. 136 i nn.: Appendice B: „Sacrament du monde”? 
element boski był jedynie tym, co w każdym człowieku jest transpersonalnego. Teksty te nie przechodzą, ale obsesja zniesienia dwoistości: ubóstwienie-uczłowieczenie pojawia się ponownie w zmienionej formie w trzy lub cztery lata po Soborze.

Jan Paweł II mówił niedawno w Issy-les-Moulineaux ${ }^{41}$ : „Jedni (progresiści) z niecierpliwością chcą dostosowywać nawet samą treść wiary, etykę chrześcijańską, liturgię, organizację kościelną do zmian mentalności, do tego czego wymaga ,,świat”, nie tylko nie licząc się dostatecznie z powszechnym odczuciem wiernych, którzy są zdezorientowani, ale i z tym, co jest istotne w wierze i już zdefiniowane, z korzeniami Kościoła, jego wiekowym doświadczeniem, jego jednością i uniwersalnością. Są oni owładnięci ideą ,postępu”, ale jakiego ostatecznie ,postępu”?

\section{Jak ożywić Sobór?}

a) Jestem być może utopistą, ale marzyłbym o systematycznych badaniach Vaticanum II w cyklu studiów teologicznych, nauk religijnych, w grupach badawczych.

W tym celu wysunąłbym dwa argumenty. Liczba tych, którzy mogą mówić o Soborze, wedle tego co w czasie jego trwania przeżyli i zrobili, maleje coraz bardziej. Trzeba zastąpić wspomnienia osobiste systematycznymi badaniami. Drugi argument jest następujący: o wiele łatwiej byłoby przeciwstawić się fałszywym interpretacjom Soboru i ich konsekwencjom, przedstawiając program pozytywny i systematyczny, zamiast podbiegać to tu to tam, by odpowiedzieć na te fałszywe interpretacje.

Krótko mówiąc, to co tutaj proponuję to ekwiwalent tego co uczynił XVII i XVIII wiek. W owych czasach Fakultety i Seminaria zorganizowały systematyczne badania nad Soborem Trydenckim. Studia te zostały przerwane dopiero w czasie wydarzeń roku 1789.

b) W każdym razie niezależnie od tego czy zaakceptuje się czy nie te specyficzne badania Vaticanum II, trzeba by ponaglić jego włączenie w dzieła systematyczne do studiowania dogmatyki, teologii moralnej, egzegezy, prawa.

W teologii moralnej, muszę to stwierdzić, nie zostało to dokonane. W roku 1969, Ojciec Van Kol, przedstawiał ,pierwszą posoborową teologię moralną" ${ }^{42}$. Musieliśmy stwierdzić, że takie przedstawienie dzieła dotyczyło jedynie daty wydania. Autor publikuje stare wykłady, doda-

${ }^{41}$ Jan Pawel II, Discours aux Evêques de France, w: L'Osservatore Romano français z 3 czerwca 1980 , s. 15.

42 A. Van Kol, Theologia moralis, Herder, 1968, 2 tomy. 
jąc niekiedy parę cytatów soborowych. Potem w 1975 r. ukazała się Chiamata e Risposta Dom Anselme Gunthora ${ }^{43}$. To już było coś więcej. Niektóre rozdziały były soborowe, ale inne zostały zamknięte na jego wpływ. Ale przez cały ten czas, inni autorzy proponowali i rozwijali meta-moralność meta-Soboru.

Integracja Soboru w nauczanie teologii jest procesem wymagającym o wiele więcej czasu i trudniejszym niżby się wydawało. To problem personelu, który należałoby odnowić lub przynajmniej nie przytłaczać obłędnym obciążeniem dydaktycznym. Być może, udawałoby się rozpocząć systematyczne syntezy paroma traktatami dotyczącymi niektórych części teologii moralnej.

c) Ożywić ponownie Sobór na płaszczyźnie życia Kościoła. Jednym z doświadczeń, jakie przyniósł nam obecny kryzys jest fakt, że większość wiernych zareagowała lepiej niż księża i teologowie. Wszyscy byliśmy zażenowanymi świadkami liturgii eucharystycznych, w których jedyną przestrzeganą regułą było: „czynić inaczej niż nakazują oficjalne księgi". Gdyby przyjrzeć się bliżej antykonformizmowi, znaleźlibyśmy tam, jak sądzę, coś w rodzaju fanatyzmu nieposłuszeństwa. Wielu duchownych czuło się przytłoczonych autorytetem przedsoborowym... chociaż zdali sobie z tego sprawę dopiero potem. Mają za sobą cudowne doświadczenie, które jeden z nich tak streścił: „Nigdy nie udało nam się niczego otrzymać inaczej jak przez nieposłuszeństwo i kontestację".

Proces taki, może rzeczywiście, zwyciężyć, ale tylko do chwili, kiedy stosują go wszyscy. A tutaj dochodzi do głosu praxis fidelium. Coraz bardziej odsuwa się od ekscesów i popiera jedynie tę część postępu, która jest zdrowa. Najczęściej wierni mogą wybierać między paroma nabożeństwami w tym samym mieście, a w każdym razie mogą wyrażać swoje opinie.

W sprawach teologicznych sytuacja jest bardziej skomplikowana. Ale rozjaśnia się często, kiedy zadać sobie trud sformułowania tego, czego domagają się awangardziści. Na 100 zwolenników Hansa Künga, niespełna dziesięciu zna dokładnie jego idee na temat Chrystusa. Jego zdaniem Jezus nie wiedział, że umrze za nas i nie mógł myśleć o założeniu Kościoła, ponieważ Królestwo Boże miało natychmiast nastać na ziemi. Został włączony w wielkość całkowicie boską, kiedy Bóg go zbudził z martwych. Postawienie wiernych wobec tego rodzaju twierdzeń jest, jak sądzę, o wiele lepszym zwalczaniem meta-Soboru niż podejmowanie wielkich polemik na planie jedynie naukowym.

Ponieważ lud chrześcijański - jak to mówi Vaticanum II - cieszy się asystencją Ducha Swiętego, Duch Swięty prowadzi go by słuchał pa-

${ }^{43}$ A. Gunthor, Chiamata e risposta, Una nuova teologia morale, Edizioni Paoline, Roma, 1975, 3 tomy. 
sterzy prawowitych w wierności Wierze opartej na Piśmie Swiętym i Tradycji.

Dlatego właśnie możemy zakończyć te stronice często nazbyt czarne - za co przepraszam - optymizmem chrześcijańskim. Przyjdzie dzień, kiedy cały lud chrześcijański zrozumie łaskę światła i siły, którą Bóg mu uczynił w II Soborze Watykańskim. A kiedy je zrozumie i przyswoi, będzie radośnie mógł szukać post-Soboru, który nie będzie meta-Soborem:

Z francuskiego przełożyła Elżbieta Jogatła 